\title{
THE DISTINCTIONS OF THE BEGINNING PRAYING TIME CALCULATION BY RINTO ANUGRAHA
}

\author{
Raizza Kinka Intifada ${ }^{1}$, Ahmad Izzuddin ${ }^{2}$ \\ ${ }^{1}$ Tim Hisab Rukyat Menara Al-Husna Masjid Agung Jawa Tengah, ${ }^{2}$ Universitas Islam Negeri \\ Walisongo Semarang \\ 1aizzakinka19@gmail.com, ${ }^{2}$ izzuddin 2008@yahoo.com
}

\begin{abstract}
:
Praying (Shalat) is a fundamental ritual for moslem. Moslem must have deep understanding about praying time in doing Shalat. In this era, many astronomy and falak scholars make a guideline or formula of an algorithm of the beginning of praying time calculation. One of them is a physic lecturer from Gajah Mada University who concern about calculation, specifically about Islamic astronomy (Falak). He designs algorithm of the beginning of praying time schedule on his book "Mekanika Benda Langit (Celestial Mechanics)" and his personal blog to access the program of the beginning praying time calculation. This work is a kind qualitative research which use library research method. By using descriptive explanatory method, the author will scrutinize factor which differ the calculation of the beginning praying time by Rinto Anugraha that will be compared to the beginning of praying time by Ministry of Religious Affairs of Indonesia. In this study, the authors analyzed that the solar declination data and the equation of time used were calculated manually by looking for initial data from Julian Day. The program presented in the early Rinto Anugraha prayer time algorithm based on modern astronomy is very friendly for the user. In the implication of hisab, Rinto Anugraha uses a constant sun height of $-18^{\circ}$ for the evening prayer time and $-20^{\circ}$ for the dawn prayer time.

Keywords: Beginning, Hisab, Prayer, Time
\end{abstract}

\section{Abstrak :}

Persoalan salat merupakan persoalan fundamental dalam peribadatan seorang muslim. Dalam pelaksanaannya kaum muslimin harus memperhatikan waktu-waktu yang sudah ditentukan. seiring berkembangnya zaman, banyak ahli astronomi dan ahli falak yang membuat pedoman atau rumus algoritma hisab awal waktu salat, salah satunya Dosen Fisika Universitas Gajah Mada yang menekuni bidang hisab terutama 
pada khazanah ilmu falak merancang algoritma perhitungan awal waktu salat yang tertuang dalam bukunya Mekanika Benda Langit dan Blog pribadi miliknya untuk mengakses program hisab awal waktu salat. Penelitian ini merupakan jenis penelitian kualitatif dengan kajian penelitian kepustakaan (library research). Dengan dijabarkan secara deskriptif oleh penulis ingin mengetahui apa sajakah yang membedakan hisab awal waktu salat Rinto Anugraha yang akan dibandingkan dengan awal waktu salat Kementrian Agama RI. Pada penelitian ini, penulis menganalisis bahwa data deklinasi matahari dan equation of time yang digunakan dihitung secara manual dengan mencari data awal dari Julian Day. Program yang disajikan pada algoritma awal waktu salat Rinto Anugraha berbasis dengan astronomi modern yang sangat user friendly. Dalam implikasi hisabnya, Rinto Anugraha menggunakan ketinggian matahari yang konstan yakni $-18^{\circ}$ untuk waktu salat isya dan $-20^{\circ}$ untuk waktu salat subuh.

Kata Kunci : Awal, Hisab, Salat, Waktu

\section{A. Introduction}

Prayer is a form of worship that cannot be abandoned under any circumstances. Salat is an obligation for all Muslims and is a direct order from AllahSWT that was given to the Prophet Muhammad SAW when carrying out Isra' Mi'raj which took place on the $27^{\text {th }}$ of Rajab in the $12^{\text {th }}$ year of prophecy. In this event, Allah SWT gave the responsibility to the people of the prophet Muhammad to pray five times a day and night. Basically, prayers have been carried out since the previous prophets but in different numbers of cycles and at different times. ${ }^{1}$

Prayer is a muwaqqat worship which has a predetermined time, even if the space is determined in worship. ${ }^{2}$ As we know, the obligatory prayers for the people of the Prophet Muhammad are five times a day. Regarding its implementation, Allah only gives signs, as seen in the Surah Al-Isra verse 78:

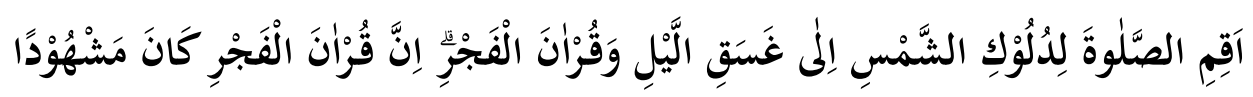

"Establish prayers from the time the sun culminated until dark, and also establish the dawn prayers, the morning prayers are witnessed by angels. "3

${ }^{1}$ Slamet Hambali, "Ilmu Falak 1: Penentuan Awal Waktu Shalat \& Arah Kiblat Seluruh Dunia.", (Semarang: Program Pascasarjana UIN Walisongo, 2011), 103

${ }^{2}$ Muhammad Hadi Bashori, "Pengantar Ilmu Falak: Pedoman Lengkap Tentang Teori Dan Praktik Hisab, Arah Kiblat, Waktu Salat, Awal Bulan Qamariah \& Gerhana”, (Jakarta Timur: Pustaka Al-Kautsar, 2015), 145

${ }^{3}$ Departemen Agama RI, Al-Quran Dan Terjemahannya, (Semarang: Toha, 2005) 
It is also explained in chapter Hud verse 114:

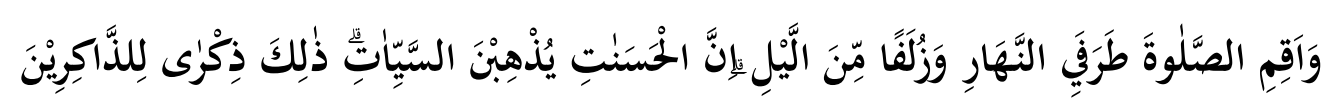

"And establish the second prayer on the edge of the day (morning and evening) and on the part of the beginning of the night. Good activities can erase the mistakes, that is a warning for those who always remember (Allah)."

The Koran does not clearly explain when the schedule of praying time. The prayer times shown are only explained in the hadith of the prophet in the form of natural phenomena such as the time of the midday prayer, which is when seeing the sun culmination. Also, for the Asr prayer time, we have to leave the house using a stick then measure and compare the length of the stick with the length of its shadow. ${ }^{5}$

The issue of prayer time is very important. If the clock of the hourly instrument is faster than the preset time, the prayer time will be shorter and vice versa, if the predetermined time is slower, the prayer time will be slower. The impact is significant since determining the time of prayer outside the time has a very big risk. As explained in the text, incorrect time can invalidate prayer times. The problem will be even greater if the error in prayer times is followed by many people or congregations at a place of worship. The invalidity of prayers can also have an effect on fasting, because when entering the Ramadan period the problem is getting more complicated because there is an additional time for the prayer and cannot be separated from the prayer time (Fajr and Maghrib).

Since rapid development of the technology, the initial determination of prayer times can be determined easily by existing technology, without having to measure the movement of the sun daily. Practitioners of falak and astronomy, especially in Indonesia, have begun to determine the height of the sun from the horizon (the equator) which can be used as a reference in calculating the prayer time schedule with the scientific

\footnotetext{
${ }^{4}$ Departemen Agama.

${ }^{5}$ Muhyiddin Khazin, "Ilmu Falak Dalam Teori Dan Praktik: Perhitungan Arah Kiblat, Waktu Shalat, Awal Bulan Dan Gerhana”, (Yogyakarta: Buana Pustaka, 2004), 79
} 
calculation. In Indonesia, it has an all-time prayer schedule that can be used practically, without doing calculations every day. ${ }^{6} \mathrm{We}$ can also find praying time practically by using softwares, literatures written by falak scholars which have methods and steps in determining the beginning of praying time that recently emerged. The development of this knowledge, Muslims in carrying out their prayer obligations only adhere to the prayer time schedule hours without having to make observations first.

One of the literature which provide steps in determining the beginning and ending of praying time "Mekanika Benda Langit " by Rinto Anugraha. Rinto Anugraha has used contemporary calculation such as referring data of the Sun from Jean Meeus' algorithm. Besides, Rinto used Accurate Times software by Mohammad Odeh as a guideline since the software has used VSOP87 algorithm for the Sun's movement and ELP2000 algorithm for the Moon's movement. ${ }^{7}$

According to Rinto Anugraha, in the calculation of the beginning of the maghrib time and the rising altitude that appears is $0^{\circ}$. However, in the calculation, the altitude is not $0^{\circ}$ but $-0.8333^{\circ}$ or -50 '. This number comes from two things, the first is the angle for the average radius of the sun is 16 ', the second is the magnitude of the correction of atmospheric refraction when celestial bodies are in the horizon (at sunrise or sunset) on average $34^{\prime} .8$

Furthermore, Rinto Anugraha explained the formula for sunrise and sunset time. The factor of the height of the location $(\mathrm{H})$ above sea level has also been taken into account. Someone who is high enough above sea level will witness an earlier sunrise and a later sunset than people who are on the surface of the sea. In this case, the formula for finding the lower horizon is -0.0347 * SQRT (H). ${ }^{9}$ In short, the formula can be generated as follow $-($ ref $+\mathrm{SD}+\mathrm{KU})$.

\footnotetext{
${ }^{6}$ The prayer time schedule is usually displayed in several prayer rooms and mosques. In addition, these schedules are the results of calculations by the reckoning experts by using the spherical triangle formula that has not been simplified. The letters used are abajadun letters and the goniometric function obtained by using rubu 'mujayyab

${ }^{7}$ Rinto Anugraha, "Mekanika Benda Langit", (Yogyakarta: FMIPA UGM, 2012), 94

${ }^{8}$ Anugraha, 94

${ }^{9}$ Anugraha, 95-96
}

Al-Hilal: Journal of Islamic Astronomy, Vol. 3, No. 1, 2021

p-ISSN : 2775-1236 ; e-ISSN : 2775-2119 
Besides, Rinto Anugraha pays close attention to the accuracy of the data that will be calculated, in this case the sun's declination data and the equation of time. According to him, most of the initial calculations of prayer time use the data value of the sun's declination and the equation of time at 12.00 local time. Meanwhile the value of the sun's declination and the equation of time always change every time even though the change is quite small in the span of one day. Therefore, the beginning of the prayer time can be refined or corrected even better if it is for each prayer time. The value of the sun's declination and the equation of time used are in accordance with the value at the time of the prayer. ${ }^{10}$

The above corrections are oftenly overlooked in calculating the initial prayer times. Even though the calculation provided in the book "Mekanika Benda Langit" Rinto Anugraha can be used as a guideline in determining the initial time of prayer. Related to this issue, the writer wants to study and analyze the algorithm about the calculation of the initial prayer time of Rinto Anugraha in the book "Mekanika Benda Langit".

\section{B. Method}

The research is categorized as qualitative research by using library research approach. ${ }^{11}$ The author concerns to the results of the beginning of praying time calculation by Rinto Anugraha in his book "Mekanika Benda Langit". The research will also compare the positive and negative sides of the calculation result by using descriptive approach. ${ }^{12}$ This work will depict algorithm of Rinto Anugraha's method in determining the beginning of praying time.

\section{Discussion and Results}

\section{C.1. Rinto Anugraha's Biography}

Rinto Anugraha was born in Jakarta, September 27, 1974. He is the eldest of his three siblings. He accomplished his formal education at SDN Klender 15,

\footnotetext{
${ }^{10}$ Anugraha, 95

${ }^{11}$ Saifuddin Azwar, "Metodelogi Penelitian”, (Yogyakarta: Pustaka Pelajar, 2010), 91

12 Suryabrata Sumadi, "Metodelogi Penelitian”, (Jakarta: Raja Grafindo Persada, 2009), 76
} 
SMPN 6, SMAN 59 in East Jakarta. Then, he pursued his higher education at UGM physics study program from 1992 to 1997 with a research entitled General Relativity and Cosmology. Rinto Anugraha continued his studies at the UGM Masters in Physics study program in 1997-2001. Rinto Anugraha became a lecturer assistant at UGM during his master study. In the midst of a busy life and a career as a lecturer assistant, Rinto Anugraha succeeded completing his master's study with the research title Renormalization and Dimensional Regularization in Quantum Field Theory.

Furthermore, Rinto Anugraha has an opportunity to get a Monbugakusho scholarship sponsor in the field of Nonlinear Physics Diapplied Physics Laboratory at Kyushu university with the topic of research on Turbulence In Liquid Crystals (Soft-Mode Turbulence) in 2008-2010. Postdoctoral researchers at Kyushu University with JSPS sponsors.

After returning from Japan, he served as a Head of the Laboratory Material Physics and Instrumentation Department of Physics UGM FMIPA for 4 years starting from 2011-2015. Since he has ingenuity in the field of physics, he actively teaches several courses at the undergraduate and postgraduate degrees of physics at UGM and the other major in Basic Physics, Mathematical Physics, Electrodynamics, Classical Mechanics, Theory of Relativity, Quantum Physics, Mechanics of Celestial Bodies, Kapita Selekta in Material Physics and so on. Therefore, he decided to stay with his family in Krangkungan, Condong Catur Depok Sleman Yogyakarta.

His work in the field of physics leads Rinto Anugraha to study astronomy, especially in the science of computation. He pursued hisab by self-taught while studying in Japan. The reference book he studied and greatly influenced his interest in the field of computation, namely the book by Jean Meeus entitled Astronomical Algorithm. Since reading this book, Anugraha was inspired to the study of astronomy and the science of computation.

His passion for learning has been expressed in several studies in the journal of international physics, such as, Physical Review Letters, Physicals Review E. Journal of the Physicals Society of Japan, Physica D and others. Moreover, he is also 
active as a speaker in seminars and studies on the science of hisab and astronomy. He became a speaker in the study of astronomy in Fukuoka, Japan in 2009, and several seminars on astronomy at UIN Walisongo. Since he often became a speaker for astronomy seminars at UIN Walisongo, then he invited as a guest lecturer in the field of astrophysics at the master and doctoral programs at UIN Walisongo since 2011. ${ }^{13}$

Besides, being a physic lecturer in UGM, he actively learning foreign languages especially English, and publicshed a TOEFL book. In fact, he also wrote a book on Academic Potential Test (TPA) and Physics Olympiad Book published by Gava Media publisher. There are also books on the theory of relativity and cosmology and his fourth book, Mechanics of celestial bodies (Mekanika Benda Langit) published by Gadjah Mada University Press. Currently, he is actively writing on his personal website.

Rinto Anugraha's field interests include physics (general relativity and cosmology, mathematical physics, electromagnetics, liquefied crystals, spin magnetic simulations, chaos), computation (theory and computation). He also expert in image software (for image processing), basic language, HTML, and a little JAVA programming. Due to his expertise in physics, he has experience in handling physics Olympiad training for junior and senior high school levels. Moreover, he studied autodidactically classic astronomy from classical astronomy books as wel as learning and reading Arabic writing, especially interpretation (tafsir) and proselytizing (da'wah) fiqh.

\section{C.2. Rinto Anugraha's Algorithm of the Beginning Praying Time}

In calculating the prayer time, Rinto Anugraha is based on the book Astronomical Alghorithm by Jean Meeus. Therefore, there are some data that must be known because there are several different data with the other astronomical literatures. Some algorithm datas used by Rinto Anugraha in determining the start of prayer time, as follow:

\footnotetext{
${ }^{13}$ Rinto Anugraha, "Interview by Phone with Rinto Anugraha at Friday, 23 $3^{\text {th }}$ of April 202113.00 WIB."
} 
The first, we have to find place coordinate data includes place latitude $(\theta)$ and longitude $(\lambda)$ as well as the height of the place from sea level. Place coordinates data can be accessed via GPS, tables, maps, etc. Meanwhile, the place altitude is searched by an altimeter or GPS. ${ }^{14}$ Then, time zone (Z) is also important data.

The second, determining the date (D), month $(\mathrm{M})$, and year $(\mathrm{Y})$ of the Gregorian calendar. This data becomes a parameter to determine the prayer time on that date. From this data, the Julian day (JD) value is then calculated. Then, the angle of the date $\mathrm{T}$ is calculated with the formula:

$\mathrm{T}=2 * \mathrm{PI}^{*}(\mathrm{JD}-2451545) / 365,25$

PI is a constant which is worth 3.14159265359. Meanwhile 2451545 is JD for January 1,2000 at 12.00 UT. The number 365.25 is the average number of days in a year. Then, $\mathrm{T}$ stands for the date angle in a year starting from January 1, 2000 at 12.00 UT. $^{15}$

The third, finding the sun's declination angle (Delta). In the process of calculating the solar declination data, it differ to the other astronomic literature. This is because of the data collection, the declination of the sun is calculated on a certain date at certain hours of prayer time which will be calculated using the following formula:

Delta $=0,37877+23,264 * \operatorname{SIN}\left(57,297^{*} \mathrm{~T}-79,547\right)+0,3812 * \operatorname{SIN}(2 * 57297)^{*} \mathrm{~T}$ $82,682)+0,17132 * \operatorname{SIN}(3 * 5729 * T-59,722)$

Fourth, finding the equation of time (ET) for a certain date can be calculated as follows. Initially, it is necessary to calculate the mean longitude of the sun LO by this formula:

$\mathrm{LO}=280,466607+36000698^{*} \mathrm{U}$ on degrees unit

$\mathrm{U}=(\mathrm{JD}-2451545) / 365,25$

Then, Equation of time can be formulated as follow: $1000^{*} \mathrm{ET}=$ $\left(1789+237^{*} \mathrm{U}\right) * \operatorname{SIN}(\mathrm{L} 0)-\left(7146-62^{*} \mathrm{U}\right){ }^{*} \mathrm{COS}(\mathrm{L} 0)+(9934-14 * \mathrm{U}){ }^{*} \mathrm{SIN}(2 * \mathrm{~L})-$

\footnotetext{
${ }^{14}$ Slamet Hambali, "Ilmu Falak 1: Penentuan Awal Waktu Shalat \& Arah Kiblat Seluruh Dunia”, (Semarang: Program Pascasarjana UIN Walisongo Semarang, 2011), 141

${ }^{15}$ Anugraha, "Mekanika Benda Langit", 89
} 
$\left(29+5^{*} \mathrm{U}\right)^{*} \operatorname{COS}\left(2^{*} \mathrm{LO}\right)+\left(74+10^{*} \mathrm{U}\right) * \operatorname{SIN}\left(3^{*} \mathrm{LO}\right)+\left(320-4^{*} \mathrm{U}\right){ }^{*} \operatorname{COS}\left(3^{*} \mathrm{~L} 0\right)-$

\section{$212 * \operatorname{SIN}(4 * \operatorname{LO})$}

The left side of the equation above is still worth 1000 times ET. Thus the result must be divided by 1000 to get ET. The unit of ET is minute. ${ }^{16}$

The fifth, determining the altitude when the sun is at dawn and isha. Subuh during the dawn is called dawn astronomical twilight, which is when the sky is no longer dark where the earth's atmosphere is able to refract sunlight from under the horizon. Meanwhile, isya is usually called dusk astronomical twilight when the sky appears dark because the sunlight under the horizon can no longer be refracted by the atmosphere. In astronomical standards, the altitude angle for astronomical twilight is $-18^{\circ}$ below the horizon, or equal to $18^{\circ}$.

However, there are various opinions regarding the altitude angle itself for dawn and isha. Among them the range is $15^{\circ}-18^{\circ}$. Thus the difference in the angle used will cause a difference when the time of dawn comes. Therefore, Rinto Anugraha's prayer time calculation program provides an offer of the altitude provision itself. It between $15^{\circ}$ and $20{ }^{\circ} \cdot{ }^{17}$ However, Rinto Anugraha in his book "Mekanika Benda Langit" uses $-18^{\circ}$ for isha time and $-20^{\circ}$ for dawn.

a. Determining the length of the default shadow. There are two opinions in determining the beginning of the asr time according to the Imam Syafi'I stating that the image of the object at asar $=$ the height of the object + the length of the image at zuhur. Meanwhile, Hanafi's opinion states that the length of the image of the object when it is asar = twice the height of the object + the length of the zuhur image. ${ }^{18}$ Rinto Anugraha preffer Imam syafii's opinion, which is the height of the object + the length of the image during zuhur.

b. Determining the formula of praying time according to Rinto Anugraha, as follow:

1. Transit $=12+\mathrm{Z}-\mathrm{B} / 15-\mathrm{ET} / 60$

2. Zuhur $=$ transit + correction of the Sun's declination

\footnotetext{
${ }^{16}$ Anugraha, 89

${ }^{17}$ Anugraha, 90

${ }_{18}$ Anugraha, 90
} 
3. Asar $=$ transit $+($ hour angle asar $) / 15$

4. Maghrib $=$ transit $+($ hour angle maghrib $) / 15$

5. Isya $=$ transit $+($ hour angle isya $) / 15$

6. Subuh $=$ transit $-($ hour angle subuh $) / 15$

7. The sunrise $=$ transit $-($ hour angle of the sunrise $) / 15$

From the formula above, it can be seen that the prayer time depends on the hour angle. The formula for hour angle (HA) is COS (HA) $=[$ SIN (Altitude) - SIN (Latitude * SIN (Delta)] / [COS (Latitude) * COS (Delta)] so that the formula for hour angle is ACOS (COS (HA)) The formula can be simplified to COS t0 $=\mathrm{SIN}$ h0: $\operatorname{COS} \phi x: \operatorname{COS} \delta$ - TAN $\phi x:$ TAN $\delta .{ }^{19}$

The hour angle formula above depends on the altitude. The altitude of the sun or the angle of the sun's height from the horizon is different for each prayer time.

- For asr, the altitude is $=\mathrm{ARCCOT}\left(\mathrm{KA}+\mathrm{TAN}(\mathrm{ABS}(\text { Delta- Latitude }))^{20}\right.$, and $K A=1$ for Syafii's version and 2 for Hanafi's version. The ABS symbol shows the absolute value, for example $\mathrm{ABS}(-2)=\mathrm{ABS}(2)=2$

- For maghrib, The altitude is $=-0,8333^{21}=0,0347^{*} \mathrm{SQRT}(\mathrm{H}), \mathrm{SQRT}^{22}$ shows the sign of double degree symbil, and $\mathrm{H}=$ height above the sea level.

- For isha, the altitude $=$ minus (isha angle) if the isha angle is taken $18^{\circ}$ then the isha altitude $=-18^{\circ}$.

- For dawn altitude $=$ minus (angle of dawn) if the angle of dawn is taken $20^{\circ}$ then the altitude of dawn $=-20^{\circ}$.

- For sunrise the altitude is the same as the altitude for maghrib.

${ }^{19}$ Anugraha, 91

${ }^{20}$ The language used by Rinto Anugraha is Microsoft Excel programming language, meanwhile in calculator programming language such as in Hambali's book, "Hambali, "Ilmu Falak 1: Penentuan Awal Waktu Shalat \& Arah Kiblat Seluruh Dunia."Page. 142 that is, absolute $z \mathrm{~m}=\delta \mathrm{m}-\phi x$. Then we can determine the sun's height at the initial time (ha) with the formula Cotan ha $=\operatorname{tg} z \mathrm{~m}+1$

${ }^{21}$ Altitude of maghrib and sunrise are not zero but -0.8333 degrees or equal to minus 50 arc minutes. This figure comes from two things. First, the angle for the radius of the sun is an average of 16 arc minutes. Second, the magnitude of the correction for atmospheric refraction when a celestial body is in the horizon (when it falls or falls) is an average of 34 arc minutes. Adding the two together results in 50 arc minutes below the horizon or an altitude of 50 arc minutes. See Anugraha, "Mekanika Benda Langit."Page.95-96 it is called $(\sqrt{ })$

${ }^{22}$ In the Microsft Excel SQRT programming language, however in the calculator programming language 
To illustrate, the author will calculate the beginning of praying time on 22 April 2021 at Masjid Wasilatul Muttaqien, Cangkringsari village, Sukodono, Sidoarjo, East Java as follow:

a. Latitude $(\phi x): 7^{\circ} 24^{\prime} 00^{\prime \prime}$

b. Longitude $(\lambda \mathrm{x}): 112^{\circ} 38^{\prime} 27^{\prime \prime}$

c. Altitude (height) : 3 meter above the sea level

From those data, the first step we have to find Julian Day of 22 April 2021 at 12 UT. From that date we can obtain value: $\mathrm{D}=22, \mathrm{M}=4, \mathrm{Y}=2021, \mathrm{~A}=20$ dan $\mathrm{B}=$ -13 . The result is JD $=2459327$.

Then for 22 April 2021 at 12 WIB (local time at masjid Wasilatul Muttaqien, Cangkringsari village, Sukodono, Sidoarjo), JD =2459327. $-\mathrm{Z} / 24)-7 / 24=$ 2459326,70833. Then followed by counting the date angle $\mathrm{T}=$ $2 * \operatorname{PI}(2459326,70833$ - 2451545) - 365,25 = 133,86424 radian. Therefore, we can obtain data of the Sun's declination is $(\delta)=12^{\circ} 15^{\prime} 48,564^{\prime \prime}$.

Then we have to count the value of $U=(2459326,70833-2451545) / 365,25$ $=0,21305$. Furthermore, we count the average longitude of the Sun LO $=280,46607$ $+36000,7698^{*} 0,21305$, it then converted to degree value, so LO $=138^{\circ} 45^{\prime} 43,77^{\prime \prime}$. Therefore, the results of equation of time $€=0^{\circ} 1^{\prime} 48^{\prime \prime}$.

Table 1.1 The results of the initial calculation of the Rinto Anugraha $2^{\text {nd }}$ Version prayer time algorithm without Ikhtiyat with data on the Sun's Declination and Equation of Time at the hours of each prayer time.

\begin{tabular}{cccccc}
\hline Zuhur & Asar & Maghrib & Isya & Subuh & Sunrise \\
\hline $11: 27: 58$ & $11: 48: 42$ & $17: 24: 56$ & $18: 35: 33$ & $04: 12: 10$ & $5: 30: 39$ \\
\hline
\end{tabular}

The calculations in the table above are the results of calculating the initial prayer time using the solar declination data and the equation of time at the beginning of the calculated prayer time to get more accurate results.

Table 1.2 The results of the initial calculation of the Rinto Anugraha $2^{\text {nd }}$ Version prayer time algorithm without Ikhtiyat with data on the Sun's Declination and 
Equation of Time at the hours of each prayer time with the addition of the ikhtiyat time.

\begin{tabular}{cccccc}
\hline Zuhur & Asar & Maghrib & Isya & Subuh & Sunrise \\
\hline $11: 31: 58$ & $14: 50: 42$ & $17: 26: 56$ & $18: 37: 33$ & $04: 14: 10$ & $5: 30: 59$
\end{tabular}

In the table above the initial calculation of prayer times presented by Rinto Anugraha algorithm program uses the declination of the sun and the equation of time at each prayer time with the addition of the ikhtiyat time of; the zuhur prayer time 4 minutes, asar 2 minutes, maghrib 2 minutes, isya 2 minutes, dawn / subuh 2 minutes.

Table 1.3 The results of the initial calculation of the prayer time with the Rinto Anugraha algorithm, rounding off the 2 nd Version data with the addition of Ikhtiyat. The it compared to the beginning of the prayer time of the Ministry of Religion of the Republic of Indonesia.

\begin{tabular}{ccc}
\hline Praying Time & Rinto Anugraha & $\begin{array}{c}\text { Ministry of Religious } \\
\text { Affairs of Indonesia }\end{array}$ \\
\hline Zuhur & 11.32 & 11.31 \\
\hline Asar & 14.51 & 14.51 \\
\hline Maghrib & 17.27 & 17.28 \\
\hline Isya & 18.38 & 18.38 \\
\hline Subuh & 04.15 & 04.14 \\
\hline Sunrise & 05.31 & 05.28 \\
\hline
\end{tabular}

From the table it is known that the difference between the beginning of the prayer time is not significant, such as only the difference between the various minutes and seconds which is described in the analysis below.

\section{C.3. Analysist}

Advance technological developments can influence the study of astronomy, especially with the study of Islamic astronomy (Falak). Several years until now, it can be seen some systems applied in this studies, one of which is hisab and rukyat, classical instrumental modification, and even the thinking of falak figures. The 
science of hisab has also progressed along with the development of existing technology. With the help of computer software, falak activists have begun to present various kinds of computation software that can be used as guidelines for determining the start of prayer times, determining the direction of the Qibla which can be studied online and offline.

One of the software calculation products is from an Indonesian astronomical figure namely Rinto Anugraha's prayer time schedule. Through a personal website that can be accessed publicly, it provides calculation products, not only the beginning of the prayer time but also determining the direction of the Qibla, determining the start of the lunar month, etc.

Rinto Anugraha's algorithm of the beginning of prayer time is a software based on modern astronomy with reference to his own book entitled Mekanika Benda Langit which is a reduction of the complete VSOP87 algorithm. The algorithm has also been compared with Mohammad Odeh's accurate times software.

The data used in Rinto Anugraha's algorithm of the beginning of prayer time program uses data from his personal book Mekanika Benda Langit. It contains various formulas that such as the calculation of the beginning of the lunar month, the direction of the Qibla, the coordinate system, the position of the sun, the position of the moon, the Meeus algorithm, the formula for determining eclips, and the introduction of accurate times software.

This prayer time program is a flexible program. Users can adjust according to their wishes to operate it. Users are allowed to adjust it to their needs and conditions. Consequemtly, the program can be accessed and used by all Muslims who need it on smartphones and PCs with a network connected to the internet.

Rinto Anugraha's algorithm of the beginning of prayer time program has several different data from the other calculations. Here is those differences:

The first is the solar declination and the equation of time taken by Rinto Anugraha from a systematic manual calculation that starts by finding JD data that is adjusted to the actual solar data. 
The second, the height of the sun that is used by Rinto Anugraha in his algorithm program at dawn and isya is ranging from $15^{\circ}-18^{\circ}$. Users can input according to the height they used. However, Rinto Anugraha uses the height of the Sun for Fajr time of $-20^{\circ}$ and $-18^{\circ}$ for isya on his book Mekanika Benda Langit which is according to astronomical twilight standards. Moreover, Rinto Anugraha's algorithm program uses an altitude for duha, from $3^{\circ}$ to $5^{\circ}$. It is differ from the other calculations which usually use altitude $3,5^{\circ}$. The value $-18^{\circ}$ is used because the surface of the earth is darkened. The objects in the open field can no longer be seen in shape and at that time all the stars, both brightly shining and those that weakly shinning are visible. This happens because the particle bias (red cloud) has disappeared. While the value of $-20^{\circ}$ has a bias of particle light, it's just that the light of dawn is stronger than the evening light so that the eastern horizon of the stars has begun to dim due to the strong dawn light. ${ }^{23}$

The third, Rinto Anugraha uses a sun declination correction of 2 minutes. ${ }^{24}$ It is not ikhtiyat, but it is additional correction for zuhur praying time.

Furthermore, the refraction used by Rinto Anugraha is 34 arc minutes for maghrib and sunrise as well as it is used to calculate the two prayer times. For the time of Isha and dawn, it does not use refraction, but the sun's altitude value is constant, it is $-18^{\circ}$ for isha and $-20^{\circ}$ for dawn.

The last, the use of ikhtiyat time in the implementation of prayer is one of the required ikhtiyat as a form of caution in worship. Ikhtiyat itself is actually a safety measure by adding or subtracting time so that the prayer time schedule does not precede the beginning of time or the ending of time. ${ }^{25}$ The value of ikhtiyat of Rinto Anugraha's algorithm for praying time program is 4 minutes for zuhur prayer, 2 minutes for the Asr, Maghrib, Isha and dawn prayers.

Table 1.4 The results Rinto Anugraha's calculation of the beginning of praying time with the addition of the ikhtiyat time within one year.

${ }^{23}$ Anugraha, "Mekanika Benda Langit", 90

${ }^{24}$ Anugraha, "Mekanika Benda Langit", 90

${ }^{25}$ Departemen Agama Republik Indonesia, "Pedoman Penentuan Jadwal Awal Waktu Shalat Sepanjang Masa." Directorate of Development of Islamic Religious Courts, 1994, 219 


\begin{tabular}{ccccccc}
\hline Date & Subuh/Dawn & Sunrise & Zuhur & Asar & Maghrib & Isya \\
\hline $01 / 01 / 2021$ & $3: 53: 12$ & $5: 16: 42$ & $11: 36: 59$ & $15: 01: 49$ & $17: 51: 16$ & $19: 07: 41$ \\
\hline $01 / 02 / 2021$ & $4: 10: 53$ & $5: 30: 22$ & $11: 47: 01$ & $15: 04: 13$ & $17: 47: 40$ & $19: 10: 50$ \\
\hline $01 / 03 / 2021$ & $4: 18: 09$ & $5: 34: 27$ & $11: 45: 46$ & $14: 45: 36$ & $17: 51: 05$ & $19: 01: 11$ \\
\hline $01 / 04 / 2021$ & $4: 16: 53$ & $5: 32: 20$ & $11: 37: 18$ & $14: 51: 54$ & $17: 36: 16$ & $18: 45: 38$ \\
\hline $01 / 05 / 2021$ & $4: 13: 23$ & $5: 31: 07$ & $11: 30: 33$ & $14: 49: 58$ & $17: 23: 59$ & $18: 35: 26$ \\
\hline $01 / 06 / 2021$ & $4: 14: 46$ & $5: 35: 44$ & $11: 31: 17$ & $14: 50: 33$ & $17: 20: 50$ & $18: 35: 11$ \\
\hline $01 / 07 / 2021$ & $4: 20: 47$ & $5: 42: 22$ & $11: 37: 19$ & $14: 56: 22$ & $17: 26: 17$ & $18: 41: 10$ \\
\hline $01 / 08 / 2021$ & $4: 23: 02$ & $5: 41: 54$ & $11: 39: 48$ & $14: 59: 27$ & $17: 31: 41$ & $18: 44: 08$ \\
\hline $01 / 09 / 2021$ & $4: 14: 27$ & $5: 30: 22$ & $11: 33: 28$ & $14: 50: 24$ & $17: 30: 34$ & $18: 40: 22$ \\
\hline $01 / 10 / 2021$ & $3: 58: 29$ & $5: 14: 04$ & $11: 23: 28$ & $14: 29: 18$ & $17: 26: 18$ & $18: 35: 39$ \\
\hline $01 / 11 / 2021$ & $3: 42: 12$ & $5: 01: 48$ & $11: 16: 58$ & $14: 30: 13$ & $17: 26: 09$ & $18: 38: 15$ \\
\hline $01 / 12 / 2021$ & $3: 40: 12$ & $5: 02: 53$ & $11: 22: 27$ & $14: 45: 58$ & $17: 36: 00$ & $18: 51: 42$ \\
\hline
\end{tabular}

Table 1.5 The results of the calculation of the beginning of prayer time of the Ministry fo Religious Affairs of Indonesia in a one year period.

\begin{tabular}{clllllc}
\hline Date & Subuh/Dawn & Sunrise & Zuhur & Asar & Maghrib & Isya \\
\hline $01 / 01 / 2021$ & $3: 53$ & $5: 13$ & $11: 36$ & $15: 02$ & $17: 52$ & $19: 08$ \\
\hline $01 / 02 / 2021$ & $4: 11$ & $5: 27$ & $11: 46$ & $15: 04$ & $17: 59$ & $19: 11$ \\
\hline $01 / 03 / 2021$ & $4: 18$ & $5: 31$ & $11: 45$ & $14: 46$ & $17: 52$ & $19: 01$ \\
\hline $01 / 04 / 2021$ & $4: 17$ & $5: 29$ & $11: 37$ & $14: 52$ & $17: 37$ & $18: 46$ \\
\hline $01 / 05 / 2021$ & $4: 14$ & 528 & $11: 30$ & $14: 50$ & $17: 26$ & $18: 36$ \\
\hline $01 / 06 / 2021$ & $4: 15$ & $5: 32$ & $11: 30$ & $14: 51$ & $17: 22$ & $18: 35$ \\
\hline $01 / 07 / 2021$ & $4: 21$ & $5: 39$ & $11: 36$ & $14: 57$ & $17: 27$ & $18: 41$ \\
\hline $01 / 08 / 2021$ & $4: 23$ & $5: 38$ & $11: 39$ & $15: 00$ & $17: 33$ & $18: 44$ \\
\hline $01 / 09 / 2021$ & $4: 15$ & $5: 27$ & $11: 33$ & $14: 51$ & $17: 31$ & $18: 40$ \\
\hline $01 / 10 / 2021$ & $3: 59$ & $5: 11$ & $11: 22$ & $14: 30$ & $17: 27$ & $18: 36$ \\
\hline $01 / 11 / 2021$ & $3: 43$ & $4: 58$ & $11: 16$ & $14: 30$ & $17: 27$ & $18: 39$ \\
\hline $01 / 12 / 2021$ & $3: 40$ & $4: 59$ & $11: 22$ & $14: 46$ & $17: 37$ & $18: 52$ \\
\hline
\end{tabular}

After the authors calculated the beginning of prayer times from Rinto Anugraha's version and the Indonesian Ministry of Religion of Indonesia's version, there is the 
smallest difference between the Fajr prayer time of 9 seconds in March and the largest difference of 37 seconds in May. Then, for the sunrise, the smallest difference is 3 minutes 4 seconds in October, the largest difference in August is 3 minutes 54 seconds. For zuhur prayer, the smallest difference is 18 seconds in April, and the biggest difference is 1 minute 46 seconds in February. During the Asar prayer, the smallest difference is 2 seconds in December, the largest difference is 42 seconds in October. For maghrib prayer, the smallest difference is 44 seconds in April, the largest difference is 8 minutes 41 seconds in August. During the isya prayer, the smallest difference is 8 seconds, while the largest difference is 45 seconds in November.

Overall, the difference between the beginning of the Rinto Anugraha prayer time with the Indonesian Ministry of Religion is around 2 minutes. This difference is due to rounding in computation. Besides, author argues that the difference in the calculation of the initial prayer time of Rinto Anugraha and the Indonesian Ministry of Religion is also due to differences in algorithms in calculating solar data, namely declination and equation of time. This is in accordance with the information in the book Astronomical Almanac for Computer, whose accuracy is in the range of approximately 2 minutes.

A lot of factors affect the initial calculation of prayer times, including the used height of the sun, and the altitude of the place at sea level. For the purpose of praying, these differences are still acceptable to use as a guide to the initial schedule of prayer times because such a difference can already be covered by the amount of ikhtiyat whose function is to be careful about the accuracy of the less and the excess time of calculation.

Furthermore, Rinto Anugraha's calculation of praying time has advantages and disadvantages. Here are some of the advantages according to the author's analysis after operating the program:

1. The determination of Rinto Anugraha's prayer time algorithm is in accordance with today's demands. The reality is that people today really like practical and flexible programs. It is very easy for all groups because of the systematic way of inputting data to find out the time of each prayer according to their wishes. 
Moreover, There are several ways to calculate the start of the Rinto Anugraha prayer time by opening internet access, opening the Rinto Anugraha website or blog, selecting the initial V2 prayer time program tool, manual input of the date that will be calculated at the beginning of the prayer time, as well as location coordinate data, then automatic data processing can be seen on the program of the initial praying times schedule.

2. This program is also supported with an Excel Export option that makes it easy for users to be able to download the results of the prayer time calculation. It is equipped in a neat and systematic Microsoft Excel form, so that it is easy to be understood completely with coordinate data according to user needs.

3. The results of the calculation of the initial praying time algorithm of Rinto Anugraha is equipped with ikhtiyat for each praying time, even it is detailed in hours and minutes. Therefore, users can use it easily, efficiently, and effectively. In the other hand, Rinto Anugaraha's algorithm program has some disadvantages, as follow:

1. It is difficult to manually calculated

Calculation errors can occur if calculations are done manually due to continuous calculations one by one. Rinto Anugraha's prayer time program calculates the sun's declination and the equation of time manually to obtain the initial solar data. However, this algorithm is facilitated by Rinto Anugraha's personal website or blog that can be accessed by public.

2. Human Error is potentially occured

Manual calculations of this initial prayer time algorithm have Human Error possibility, especially when user enter the data into the formula which makes it vulnerable to errors.

3. Additional rounding data

Rounding the data on the results of Rinto Anugraha's calculation program adds values up to 1 minute for prayer times. Even rounding data for excess of 1 second is rounded off by adding 1 minute. Similarly, an excess of 59 seconds is also rounded up to 1 minute.

4. It is not globally applicable 
Rinto Anugraha explains in his book Mekanika Benda Langit that the Cos to $=\operatorname{Sin} h_{0} \div \operatorname{Cos} \phi x \div \operatorname{Cos} \delta \mathrm{m}-\operatorname{Tan} \phi x \div \operatorname{Tan} \delta \mathrm{m}$, is used at high latitudes, has 3 possibilities where Cos to cannot be determined. ${ }^{26}$

The first possibility is when determining the time of dawn and isha prayer the value of cos to cannot be determined. Because the sky is visible even at 12 o'clock although the Sun is invisible. The atmosphere of the sky is like in the middle of maghrib time.

The second possibility is the case of sunrise and sunset. The formula for cos $t_{0}$, the sun never sets. The sun is always above the horizon, so with the above formula the times for dawn, sunrise, sun, maghrib, and isha prayers cannot be found, only zuhur and asr times can be obtained. For example, it occurs in regions of the northern hemisphere when the total latitude of a place with the sun's declination $(\delta)$ is $>89^{\circ} .27$

The third possibility is for the case of sunset and sunrise. In using the formula Cos $t_{0}$, the sun never rises because it is always below the horizon. Only the time of dawn and isha can be determined by the formula above. For example, it occurs in the northern hemisphere when the total latitude of a place with the sun's declination $(\delta)$ is $>91^{\circ} .^{28}$

\section{Conclusion}

According to the above explanation, author concludes that:

Firstly, Rinto Anugraha's calculation algorithm of the beginning of praying time is a kind of calculation based on a modern astronomy. The calculation of this program refers to Rinto Anugraha's personal data on his book Mekanika Benda Langit, which its formula has been compared to software Accurate Times by Mohammad Odeh.

Secondly, the differences of Rinto Anugraha's calculation is the sources of data and calculation process of the Sun's declination and equation of time which use manually and systematically calculated data. The altitude of the sun used for evening time is $-18^{\circ}$ and

\footnotetext{
${ }^{26}$ Anugraha, "Mekanika Benda Langit", 90

${ }^{27}$ Hambali, "Ilmu Falak 1: Penentuan Awal Waktu Shalat \& Arah Kiblat Seluruh Dunia”, 138

${ }^{28}$ Hambali, 138
} 
dawn time is $-20^{\circ}$. It is without using refraction but using constant sun level for evening and dawn.

Lastly, Rino Anugraha's algorithm program has some advantages; it's really up to date, it can be downloaded and accessed publicly by the internet users, and the calculation result is accurate with ikhtiyat time. In the other hand, the algorithm program has some disadvantages; it is difficult to be manually calculated since its calucaltion can caused human error, it could not globally used, and there is a rounding data on the calculation program of the beginning of praying time.

\section{E. Bibliography}

Anugraha, Rinto, Dosen Fisika Universitas Gajah Mada. "No Title." Sidoarjo, 2021. https://rintoanugraha.staff.ugm.ac.id/.

Anugraha, Rinto. "Mekanika Benda Langit." Yogyakarta: Jurusan Fisika Fakultas MIPA Universitas Gajah Mada, 2012.

Azwar, Saifuddin. "Metodelogi Penelitian.” Yogyakarta: Pustaka Pelajar, 2010.

Bashori, Muhammad Hadi. Pengantar Ilmu Falak: Pedoman Lengkap Tentang Teori Dan Praktik Hisab, Arah Kiblat, Waktu Salat, Awal Bulan Qamariah E Gerhana. Pustaka Al Kautsar, 2015.

Departemen Agama, R I. “Al-Quran Dan Terjemahannya.” Semarang: Toha, 2005.

Hambali, Slamet. "Ilmu Falak 1: Penentuan Awal Waktu Shalat \& Arah Kiblat Seluruh Dunia." Semarang: Program Pascasarjana IAIN Walisongo, 2011.

Indonesia, Departemen Agama Republik. "Pedoman Penentuan Jadwal Awal Waktu Shalat Sepanjang Masa.” Jakarta, 1994.

Khazin, Muhyiddin. Ilmu Falak Dalam Teori Dan Praktik: Perhitungan Arah Kiblat, Waktu Shalat, Awal Bulan Dan Gerhana. Buana pustaka, 2004.

Sumadi, Suryabrata. "Metodelogi Penelitian.” Jakarta: PT Rafi Grafindo, 2011. 
